Scientific journal

PHYSICAL AND MATHEMATICAL EDUCATION

Has been issued since 2013

Науковий журнал

ФІЗИКО-МАТЕМАТИЧНА ОСВІТА

Видається з 2013.

p-ISSN 2413-1571

e-ISSN 2413-158X

DOI: $10.31110 / 2413-1571$

https://fmo-journal.org/

DOI 10.31110/2413-1571-2021-032-6-009

УДК 378.14: 371.214.46

\section{ФУНДУВАННЯ ЗНАНЬ У ПРОЦЕСІ ВИВЧЕННЯ МАТЕМАТИЧНИХ ПОНЯТЬ ЗАСОБАМИ ЦИФРОВИХ ТЕХНОЛОГІЙ У ФАХОВІЙ ПІДГОТОВЦІ МАЙБУТНІХ УЧИТЕЛІВ МАТЕМАТИКИ}

\author{
Інна ШИШЕНКо $\square$ \\ Сумський державний педагогічний університет \\ імені А.С. Макаренка, Україна \\ shiinna@ukr.net \\ https://orcid.org/0000-0002-1026-5315 \\ Тетяна ЛУКАШОВА \\ Сумський державний педагогічний університет \\ імені А.С. Макаренка, Україна \\ tanya.lukashova2015@gmail.com \\ https://orcid.org/0000-0002-1465-9530 \\ Олександр СТPAX \\ Сумський державний університет, Україна \\ strah_o@ukr.net \\ https://orcid.org/0000-0002-7680-5716
}

\section{FUNDING OF KNOWLEDGE IN THE PROCESS OF STUDYING MATHEMATICAL CONCEPTS BY MEANS OF DIGITAL TECHNOLOGIES IN THE PROFESSIONAL TRAINING OF FUTURE TEACHERS OF MATHEMATICS}

\author{
Inna SHYSHENKO $\square$ \\ Makarenko Sumy State \\ Pedagogical University, Ukraine \\ shiinna@ukr.net \\ https://orcid.org/0000-0002-1026-5315 \\ Tetyana LUKASHOVA \\ Makarenko Sumy State Pedagogical \\ University, Ukraine \\ tanya.lukashova2015@gmail.com \\ https://orcid.org/0000-0002-1465-9530 \\ Oleksandr STRAKH \\ Sumy State University, Ukraine \\ strah_o@ukr.net \\ https://orcid.org/0000-0002-7680-5716
}

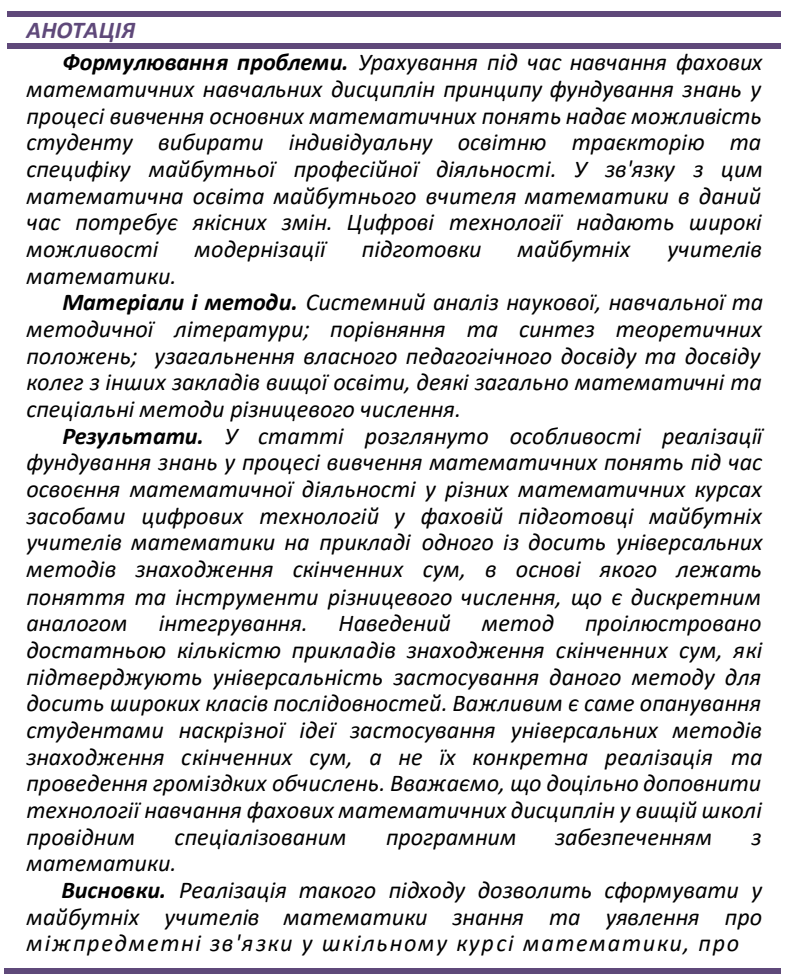

\section{АНОТАЦІЯ} час потребує якісних змін. Цифрові технології надають широкі можливості модернізації підготовки майбутніх учителі тематики. спеціальні методи різницевого числення. засобами чифров их учителів математики на прикладі одного із досить універсальних методів знаходження скінченних сум, в основі якого лежать поняття та інструменти різницевого числення, що є дискретним достатньою кількістю прикладів знаходження скінченних сум, які підтверджують універсальність застосування даного методу для досить широких класів послідовностей. Важливим $є$ саме опанування знаходже проведення громіздких обчислень. Вважаємо, що дочільно доповнити технології навчання фахових математичних дисциплін у вищій школі повідним спеціалізованим програмним забезпеченням

Висновки. Реалізація такого підходу дозволить сформувати міжпедметні зв'язки у шкільному курсі математики про

\begin{abstract}
Formulation of the problem. Taking into account the principle of funding knowledge in the study of professional mathematical disciplines in the process of studying basic mathematical concepts gives the student the opportunity to choose an individual educational trajectory and the specifics of future professional activity. In this regard, the mathematical education of the future teacher of mathematics now needs qualitative changes. Digital technologies provide ample opportunities to modernize the training of future mathematics teachers.

Materials and methods. System analysis of scientific, educational and methodical literature; comparison and synthesis of theoretical positions; generalization of own pedagogical experience and experience of colleagues from other institutions of higher education, some general mathematical and special methods of difference calculus.

Results. The article considers the peculiarities of knowledge funding in the process of studying mathematical concepts during the development of mathematical activities in various mathematical courses by means of digital technologies in the training of future mathematics teachers on the example of one of the most universal methods of finding finite sums., which is a discrete analogue of integration. This method is illustrated by a sufficient number of examples of finding finite sums, which confirm the universality of this method for a fairly wide class of sequences. It is important that students master the pervasive idea of using universal methods of finding finite sums, which is based on the concepts and tools of difference calculus, rather than their specific implementation and cumbersome calculations. We believe that it is advisable to supplement the technology of teaching professional mathematical disciplines in higher education with leading specialized software in mathematics.

Conclusions. The implementation of this approach will allow future teachers of mathematics to form knowledge and ideas about interdisciplinary links in school mathematics, the possibility of using digital technologies in the study of school mathematics, develop skills to collect, analyze, transmit mathematical information, use software and hardware devices for collecting, processing, storing and transmitting information, evaluate and select digital technologies for the organization of the
\end{abstract}

Для

цитування:

Шишенко І., Лукашова Т., Страх О. Фундування знань у процесі вивчення математичних понять засобами цифрових технологій у фаховій підготовці майбутніх учителів математики. Фізико-математична освіта, 2021. Том 32. № 6. С. 57-63. DOI: https://doi.org/10.31110/2413-1571-2021-032-6-009

Шишенко, І., Лукашова, Т., \& Страх, О. (2021). Фундування знань у процесі вивчення математичних понять засобами цифрових
майбутніх учителів математики. Фізико-математична освіта, 32(6). 57-63. https://doi.org/10.31110/2413-1571-2021-032-6-009

Shyshenko, I., Lukashova, T., \& Strakh, O. (2021). Funding of knowledge in the process of studying mathematical concepts by means of digital technologies in the professional training of future teachers of mathematics. Physical and Mathematical Education, 32(6), 57-63. https://doi.org/10.31110/2413-1571-2021-032-6-009

For

citation: Shyshenko, I., Lukashova, T., \& Strakh, O. (2021). Funduvannia znan u protsesi vyvchennia matematychnykh poniat zasobamy tsyfrovykh tekhnolohii u fakhovii pidhotovtsi maibutnikh uchyteliv matematyky [Funding of knowledge in the process of studying mathematical concepts by means of digital technologies in the professional training of future teachers of mathematics]. Fizyko-matematychna osvita - Physical and Mathematical Education, 32(6), 57-63. https://doi.org/10.31110/2413-1571-2021-032-6009 
можливості використання цифрових технологій в процесі вивчення икільного курсу математики, розвивати уміння самостійно збирати, аналізувати, передавати математичну інформацію, використовувати програмні засоби та апаратні пристрої для використовувати програмні засоби та апаратні пристрої для
здійснення збору, обробки, зберігання та передачі інформації, здійснення збору, обробки, зберігання та передачі інформаціи, навчального процесу з математики, усвідомлення можливостей інформаційного середовища для забезпечення якості навчальновиховного процесу в умовах Нової української школи.

ключовІ словА: підготовка майбутніх учителів математики цифрові технології; скінченні суми; методи підсумовування антирізницевий оператор; фахові математичні дисиипліни, антирізницевий оператор;

\section{ВСТУП}

Постановка проблеми. Стійкий розвиток інформаційного суспільства, що спостерігається на початку XXI століття, інноваційність економіки, обороноздатність нашої держави залежить від рівня математичної освіти, отриманої кожним завдяки, перш за все, шкільній освіті. Саме від учителя математики, який у школі для учня є не тільки джерелом нового предметного знання, а й, відповідно до концепції Нової української школи, провідником сучасних ідей, методів, технологій, що забезпечують формування в учнів компетентностей, орієнтують їх на найбільш ефективні способи діяльності під час розв'язування різних задач, залежить підготовка майбутніх кваліфікованих фахівців. Важливість математичної освіти визначає значущість якісної фахової підготовки майбутнього вчителя математики у 3 ВО.

Відповідно до Галузевих стандартів майбутній учитель математики має бути готовий не лише до діяльності у закладах загальної середньої освіти, але й до проведення фундаментальних та прикладних досліджень. Тому урахування під час навчання фахових математичних навчальних дисциплін принципу фундування знань у процесі вивчення основних математичних понять надає можливість студенту вибирати індивідуальну освітню траєкторію та специфіку майбутньої професійної діяльності. Урахування принципу фундування під час конструювання змісту професійної освіти вчителя математики $€$ важливою умовою забезпечення якості фундаментальної математичної підготовки студентів математичних спеціальностей педагогічних ЗВО. У зв'язку з цим математична освіта майбутнього вчителя математики в даний час потребує якісних змін. Цифрові технології надають широкі можливості модернізації підготовки майбутніх учителів математики на основі інформаційної взаємодії між студентами, викладачами та всіма іншими учасниками освітнього процесу в різних режимах роботи, виступаючи як доступне джерело отримання інформації, зокрема навчальної, як середовище освітньої комунікації.

у звО під час вивчення фахових дисциплін застосовуються комп'ютерні навчальні програми, за своїм призначенням їх можна розділити на контролюючі (тести, опитувальники та ін.), довідково-інформаційні (бази даних, словники), моделюючі та електронні підручники (Drushlyak, Semenikhina, Bondarenko, Kondratiuk\&Dehtiarova, 2019). Paзом 3 тим, навіть побіжний аналіз реальної ситуації, що склалася в педагогічних 3ВО, дозволяє зробити висновок про стихійне використання засобів цифрових технологій при навчанні студентів математичних спеціальностей. Жоден з наявних в даний час друкованих навчальних посібників для 3ВО з математики, зокрема, з алгебри, математичного аналізу, геометрії, не передбачає можливість формування та розвитку умінь, спрямованих на оволодіння майбутнім учителем математики всім спектром застосування цифрових технологій.

Аналіз актуальних досліджень. Основні положення щодо національної освіти і ролі педагогічних кадрів знайшли відображення у законах України «Про освіту», «Про вищу освіту», Державній національній програмі «Освіта» (Україна XXI століття), Національній стратегії розвитку освіти в Україні, Державній програмі «Вчитель», Концепції «Нової української школи», Професійному стандарті «Вчитель початкової школи закладу загальної середньої освіти» (2018) та ін. Про нові вимоги до структури змісту освіти і умов реалізації освітнього процесу, що передбачає кардинальну зміну процесу підготовки вчителів в умовах розвитку інформаційного суспільства, наголошено в указах Президента України «Про заходи щодо розвитку національної складової глобальної інформаційної мережі Інтернет та забезпечення широкого доступу до цієї мережі в Україні», «Про невідкладні заходи щодо забезпечення та розвитку освіти в Україні», «Про додаткові заходи щодо підвищення якості освіти в Україні», Концепції розвитку цифрової економіки та суспільства України на 2018 - 2020 pр., основною метою якої є реалізація ініціатив «Цифрового порядку денного України 2020», що охоплює широкий спектр напрямів, одним із яких є сфера освіти, та інші державні документи, спрямовані на забезпечення відповідних умов для ефективного використання інформаційних технологій з метою вдосконаленню освітнього процесу на всіх рівнях освіти.

Теоретичною основою дослідження слугують наукові праці, у яких визначено теоретичні та методологічні засади підготовки вчителя (Т. Дерека, О. Лаврентьєва, О. Набока, О. Семеног, М. Солдатенко та ін.), обґрунтовано основні проблеми підготовки майбутніх учителів в умовах розвитку інформаційного суспільства (О. Акімова, Н. Глузман, О. Дубасенюк, М. Друшляк, О. Пометун, О. Савченко, О. Семеніхіна та ін.), висвітлено теоретико-практичні засади ефективності використання інформаційних технологій та спеціалізованого програмного забезпечення в освітньому процесі (В. Биков, І. Богданова, М. Жалдак, В. Лапінський, С. Литвинова, Н. Морзе, О. Семеніхіна та ін.), схарактеризовано сутність електронних освітніх ресурсів та надано їхню класифікацію (В. Вембер, Л. Гризун, О. Кузьмінська та ін.), застосування електронних освітніх ресурсів у навчанні школярів (М. Беляєв, О. Власій, В. Гришкун, В. Гура, О. Дудка та ін.).

Професійна особливість сучасного вчителя математики полягає в тому, що в даний час його діяльність набуває випереджальний, проєктний характер i, як наслідок, ключовою вимогою до професійних якостей вчителя стає не лише оволодіння фундаментальними математичними знаннями, але й їх застосування у різних математичних курсах, а також вільне володіння цифровими технологіями для ефективної реалізації змісту, методів, форм, засобів освіти відповідно до цілей і пріоритетів, що задаються державою.

Мета статті: розглянути особливості реалізації фундування знань у процесі вивчення математичних понять під час освоєння математичної діяльності у різних математичних курсах засобами цифрових технологій у фаховій підготовці майбутніх учителів математики. 


\section{МЕТОДИ ДОСЛІДЖЕННЯ}

У статті використано наступні теоретичні та емпіричні методи досліджень: системний аналіз наукової, навчальної та методичної літератури; порівняння та синтез теоретичних положень, розкритих в науковій та навчальній літературі; узагальнення власного педагогічного досвіду та досвіду колег з інших закладів вищої освіти. Окрім того, були використані деякі загально математичні та спеціальні методи різницевого числення.

\section{РЕЗУЛЬТАТИ ДОСЛІДЖЕННЯ}

В епоху математизації наук, тобто процесу проникнення математичних ідей і методів у різні галузі знання особливо важливу роль відіграє впровадження цифрових технологій у математичну підготовку майбутніх вчителів, оскільки саме цим технологіям належить фундаментальна роль в інформаційному забезпеченні математичних досліджень у всіх науках, назви яких відображені у переліку відповідних навчальних предметів середньої загальної освіти (Drushlyak\&Semenikhina, 2015; Drushlyak et al., 2018). Це, у свою чергу, робить актуальною та практично значущою математичну підготовку майбутнього вчителя математики, його активну діяльнісну позиція студента у процесі придбання ними нових знань та умінь вирішувати професійні завдання, різноманітну взаємодію суб'єктів освітнього процесу, використання широкого спектра цифрових технологій для підтримки інтелектуальних взаємодій учасників освітнього процесу. Тому важливим $є$ урахування фундування знань у процесі вивчення математичних понять під час освоєння математичної діяльності у різних математичних курсах (Семеніхіна et al., 2019; Drushlyak et al., 2020).

Розглянемо реалізацію цього принципу з урахуванням упровадження цифрових технологій на прикладі знаходження скінченних сум та одного з методів підсумовування, що базується на властивостях антирізницевого оператора. Задачі на підсумовування досить часто виникають як у самій математиці, так і при дослідженні багатьох явищ природознавства. Зокрема, вони зустрічаються в елементарній математиці (знаходження суми перших $n$ натуральних чисел, знаходження суми $n$ перших членів арифметичної та геометричної прогресій), у класичному аналізі (знаходження суми ряду, наближене знаходження площ фігур тощо), у вищій алгебрі, комбінаториці, теорії ймовірностей, статистиці тощо. Відповідно, досить різноманітними є методи знаходження сум.

Для знаходження скінченних сум використовують наступні прийоми та методи: тотожні перетворення та властивості сум (як загальні, так і спеціальні), зведення до вже відомих сум, рекурентні співвідношення, твірні функції, диференціювання та інтегрування, засоби різницевого числення, методи теорії ймовірностей, геометричні міркування тощо (див., наприклад, (Бекішев \& Кратко, 1981; Волков \& Войналович, 2000; Мартиненко \& Чкана, 2017; Ушаков, 2004; Ушаков, 2005; Ушаков, 2006; Ушаков, 2008).

Широкий спектр засобів знаходження скінченних сум дає дискретна математика. Одним із них є застосування антирізницевого оператора, який дозволяє знаходити суми членів досить широких класів послідовностей та демонструє дієвість застосувань дискретної математики до розв'язування такого роду задач. Зазначимо, що зв'язки між окремими понятями дискретної математики, диференціального числення та теорії диференціальних рівнянь розглядалися авторами раніше (Страх\&Лукашова, 2021; Лукашова\&Страх, 2021).

Розглянемо застосування антирізницевого оператора до знаходження скінченних сум та наведемо необхідні для цього означення та твердження (Андерсон, 2004; Волков\& Войналович,2000; Kelley\&Peterson, 2001; Ядренко, 2004).

Нехай функція $f(x)$ така, що область визначення разом з точкою $x$ містить точку $(x+h)$. Оператор

$$
\Delta f(x)=f(x+h)-f(x)
$$

називається різницевим оператором (або оператором спадної різниці, або скінченною різницею першого роду) (Волков\&Войналович,2000).

Далі значення різницевого оператора називатимемо різницею (в аналізі використовується назва «приріст») $і$ позначатимемо його символом $\Delta f$. Окрім того, будемо вважати, що $h=1$, тобто

Приклад 1. $\Delta x=(x+1)-x=1$;

$$
\Delta f=f(x+1)-f(x) \text {. }
$$

$$
\begin{gathered}
\Delta 2^{x}=2^{(x+1)}-2^{x}=2^{x}(2-1)=2^{x} ; \\
\Delta x^{2}=(x+1)^{2}-x^{2}=2 x+1,
\end{gathered}
$$$$
\Delta\left(\frac{1}{x}\right)=\frac{1}{x+1}-\frac{1}{x}=\frac{x-1-x}{(x+1) x}=-\frac{1}{x(x+1)}
$$$$
\Delta x !=(x+1) !-x !=x \cdot x !
$$

Окремо розглянемо знаходження різниці для додатного узагальненого степеня $x$

$$
x^{(n)}=x(x-1)(x-2) \ldots(x-n+1), n \in \mathbb{N}, x^{(0)}=1 .
$$

Маємо:

$$
\begin{gathered}
\Delta x^{(n)}=(x+1) x(x-1) \ldots(x-n+2)-x(x-1)(x-2) \ldots(x-n+1)= \\
=x(x-1)(x-2) \ldots(x-n+2)(x+1-x+n-1)=n x(x-1)(x-2) \ldots(x-n+2)=n x^{(n-1)} .
\end{gathered}
$$

Тобто,

$$
\Delta x^{(n)}=n x^{(n-1)}, n \in \mathbb{N} .
$$

Аналогічно, для від'ємного узагальненого степеня $x$, який визначається рівністю

різниця дорівнює

$$
x^{(-n)}=\frac{1}{x(x+1)(x+2) \ldots(x+n-1)}, n \in \mathbb{N},
$$

$$
\Delta x^{(-n)}=-n x^{(-n-1)} .
$$

Таким чином, узагальнена степенева функція $x^{(n)}$ відіграє у різницевому численні ту ж роль, що й звичайна степенева функція $x^{n}$ в диференціальному численні.

Наведемо основні властивості різницевого оператора, які будуть необхідні для подальших міркувань (Волков\& Войналович,2000). 
1. $\Delta(c f)=c \Delta f$, де $c$-константа (тобто, оператор $\Delta$ однорідний).

2. $\Delta(f+g)=\Delta f+\Delta g$ (отже, оператор $\Delta$ адитивний).

3. $\Delta(f g)=f \Delta g+E(g) \Delta f$, де $E$ - оператор зсуву, $E g(x)=g(x+1)$ або $\Delta(f g)=f \Delta g+\Delta f g+\Delta f \Delta g$

4. $\Delta\left(\frac{f}{g}\right)=\frac{\Delta f g-f \Delta g}{g \cdot E(g)}$

Отже, властивості різниць багато в чому повторюють властивості похідної.

Приклад 2. Обчислити значення різницевого оператора:

1) $\Delta\left(2 x^{2}+2^{x}\right)=2 \cdot(2 x+1)+2^{x}$,

2) $\Delta\left(x^{2} \cdot 2^{x}\right)=x^{2} 2^{x}+(2 x+1) E\left(2^{x}\right)=x^{2} 2^{x}+(2 x+1) 2^{x+1}=2^{x}\left(x^{2}+4 x+2\right)$.

Нагадаємо, що антирізницевою функцією для функції $f(x)$ називається функція $F(x)$ така, що

$$
\Delta F(x)=f(x) .
$$

Антирізницеву функцію (антирізницю) для функції $f(x)$ позначають $\Delta^{-1} f(x)$ або $\Delta^{-1} f$, а оператор переходу від функції $f(x)$ до $F(x)$ називають антирізницевим (Андерсон,2004; Волков\&Войналович,2000). Значення антирізницевого оператора (як і значення його неперервного аналога - невизначеного інтеграла) визначається неоднозначно: якщо $F_{1}(x)$ і $F_{2}(x)$ дві антирізниці, то $F_{1}(x)-F_{2}(x)=C(x)$, де $C(x)$ - довільна періодична функція з періодом $T=1$.

Досить часто значення антирізниці вдається підібрати, виходячи з вигляду функції $f(x)$.

Приклад 3. 1) $\Delta^{-1} 2^{x}=2^{x}+C(x)$, де $C(x)$ - періодична функція з періодом 1 , оскільки

$$
\Delta\left(2^{x}+C(x)\right)=2^{x+1}+C(x+1)-\left(2^{x}-C(x)\right)=2^{x}(2-1)=2^{x} .
$$

2) $\Delta^{-1} 3^{x}=\frac{3^{x}}{2}+C(x)$, оскільки $\Delta\left(\frac{3^{x}}{2}+C(x)\right)=\Delta \frac{3^{x}}{2}+\Delta C(x)=\left(\frac{3^{x+1}}{2}-\frac{3^{x}}{2}\right)+(C(x+1)-C(x))=\frac{3^{x}}{2} \cdot 2=3^{x}$.

3) Аналогічно, використовуючи означення різниці та антирізниці, одержимо:

$$
\Delta^{-1} x=\frac{x(x-1)}{2}+C(x)=\frac{x^{(2)}}{2}+C(x),
$$

де $x^{(2)}=x(x-1)-$ узагальнений квадрат $x$. Цей результат випливає з рівності (1) та властивості 2:

Відповідно,

$$
\Delta\left(\frac{x^{(2)}}{2}+C(x)\right)=\Delta\left(\frac{x^{(2)}}{2}\right)+\Delta C(x)=\frac{2 x^{(1)}}{2}=x .
$$

$$
\Delta^{-1} x^{(2)}=\frac{x(x-1)(x-2)}{3}+C(x)=\frac{x^{(3)}}{3}+C(x)
$$

$$
\Delta^{-1} x^{(n)}=\frac{x^{(n+1)}}{n+1}+C(x), n \neq-1, n \in \mathbb{Z} .
$$

4) Покажемо, що $\Delta^{-1}\left(\frac{x-1}{x !}\right)=-\frac{1}{(x-1) !}+C(x)$. Справді,

$$
\Delta\left(-\frac{1}{(x-1) !}+C(x)\right)=\Delta\left(-\frac{1}{(x-1) !}\right)+\Delta C(x)=\left(-\frac{1}{x !}+\frac{1}{(x-1) !}\right)=\frac{x-1}{x !} .
$$

Наведемо кілька властивостей антирізниць, які випливають з наведених вище означень:

1. $\Delta^{-1} f(x)=F(x)+C(x), C(x)$ - періодична функція, $T=1$;

2. $\Delta^{-1} c f=c \Delta^{-1} f$;

3. $\Delta^{-1}(f+g)=\Delta^{-1} f+\Delta^{-1} g$.

4. Якщо $\Delta^{-1} f(x)=F(x)$, то

\section{5. Перетворення Абеля}

$$
\sum_{k=m}^{n-1} f(x)=\left.F(x)\right|_{m} ^{n}=F(n)-F(m)
$$

де $E(g)=g(x+1)$ - оператор зсуву (Ядренко,2004).

$$
\sum_{x=m}^{n-1} f \Delta g=\left.f \cdot g\right|_{m} ^{n}-\sum_{x=m}^{n-1} E(g) \Delta f
$$

Наведені вище властивості аналогічні до властивостей оператора інтегрування, а дві останні $є$ дискретними аналогами формули Ньютона-Лейбніца та формули інтегрування частинами відповідно. Саме вони відіграють провідну роль у знаходження скінченних сум. Розглянемо застосування цих властивостей на прикладах.

Приклад 4. Обчислити суму $1+2+2^{2}+2^{3}+\cdots+2^{n}$.

У цьому випадку $f(x)=2^{x}$. Скористаємося властивістю 4), враховуючи, що $F(x)=\Delta^{-1} 2^{x}=2^{x}$. Маємо:

$$
\sum_{k=1}^{n} 2^{k}=2+2^{2}+2^{3}+\cdots+2^{n}=\left.2^{k}\right|_{1} ^{n+1}=2^{n+1}-2
$$

Приклад 5. Обчислити суму

$$
\sum_{k=1}^{n} k(k+1)=1 \cdot 2+2 \cdot 3+3 \cdot 4+\cdots+n \cdot(n+1)
$$

Позначимо $f(x)=x \cdot(x+1)=x^{2}+x$ та знайдемо ї̈ антирізницю. Для цього представимо $f(x)$ у вигляді суми узагальнених степенів $x: x^{2}+x=x(x-1)+2 x=x^{(2)}+2 x^{(1)}$. Тоді за формулою (2) і властивостями 1)-2)

$F(x)=\Delta^{-1} x \cdot(x+1)=\Delta^{-1}\left(x^{(2)}+2 x^{(1)}\right)=\frac{1}{3} x^{(3)}+\frac{2}{2} x^{(2)}=\frac{1}{3} x(x-1)(x-2)+x(x-1)=\frac{1}{3} x(x-1)(x+1)$.

Далі за властивістю 4)

$$
\sum_{k=1}^{n} k(k+1)=\left.\frac{1}{3} k(k-1)(k+1)\right|_{1} ^{n+1}=\frac{1}{3} n(n+1)(n+2)
$$


Приклад 6. Обчислити суму

У даному випадку $f(x)=x^{3}$ і

$$
\sum_{k=1}^{n} k^{3}=1+2^{3}+3^{3}+4^{3}+\cdots+n^{3}
$$

$$
\left.\Delta^{-1} x^{3}=\Delta^{-1}\left(x(x-1)(x-2)+3 x^{2}-2 x\right)=\Delta^{-1}\left(x^{(3)}+3 x^{(2)}+x^{(1)}\right)=\frac{1}{4} x^{(4)}+x^{(3)}+\frac{1}{2} x^{(2)}\right),
$$

Тому

$$
\sum_{k=1}^{n} k^{3}=\left.\left(\frac{1}{4} k^{(4)}+k^{(3)}+\frac{1}{2} k^{(2)}\right)\right|_{1} ^{n+1}=\left.\frac{1}{4}(k(k-1))^{2}\right|_{1} ^{n+1}=\frac{1}{4}(n(n+1))^{2}
$$

При розв'язуванні таких завдань виникає потреба перевірити себе, самостійно визначити правильність розв'язування завдання. Тому важливо говорити про застосування засобів цифрових технологій у математичній підготовці майбутніх учителів математики, які дозволять реалізувати обчислення та графічні інтерпретації без значних зусиль, виконати самоперевірку. На рис. 1 представлено розв'язання даного завдання засобами онлайн-калькулятора, як бачимо, відповідь збігається. Відповідно, на рис. 2 представлено застосування цього ж онлайн-калькулятора до розв'язування прикладу 4.

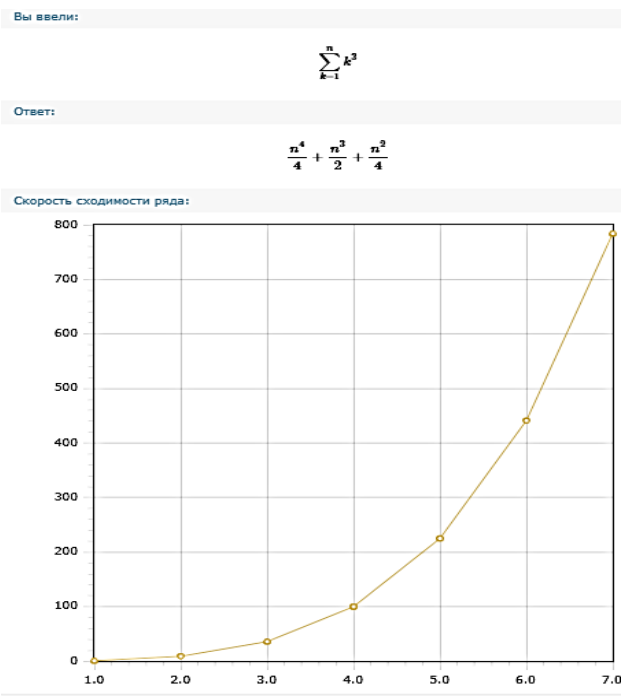

Рис. 1. Застосування онлайн-калькулятора до розв'язування прикладу 6

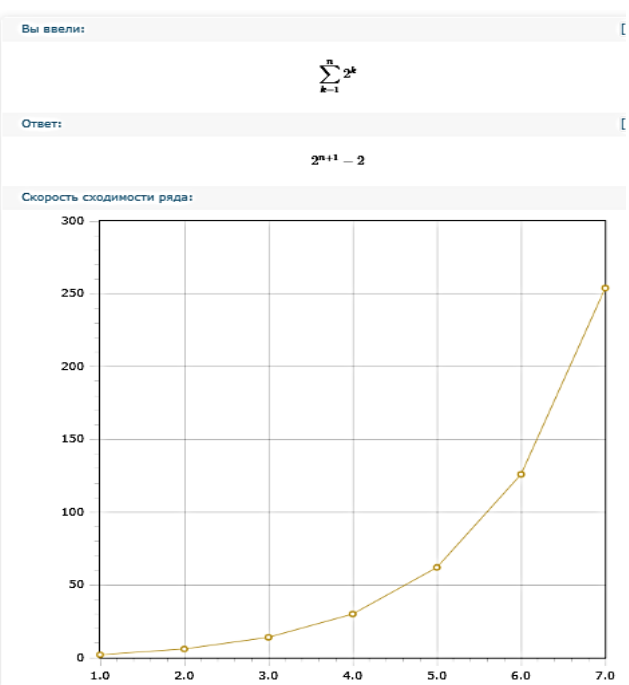

Рис. 2. Застосування онлайн-калькулятора до розв'язування прикладу 4

В останньому прикладі при обчисленні суми кубів перших $n$ натуральних чисел «вручну» довелося виконати перехід від звичайного до узагальненого степеня $x$, оскільки значення антирізниці від узагальненого степеня обчислюється дуже просто. Такий перехід (і взагалі, перехід від звичайного многочлена до так званого факторіального многочлена, що $є$ лінійною комбінацією узагальнених степенів $x$ ) реалізується кількома алгоритмами. Перший з них полягає у використанні схеми Горнера та знаходженні остач від ділення даного многочлена на $x$, утвореної частки на $(x-1)$, нової частки - на $(x-2)$ і так далі. Ці значення будуть коефіцієнтами при узагальнених степенях $x^{(k)}$ при $k=0,1,2, \ldots n$ відповідно (Андерсон, 2004).

Наприклад, для переходу від $x^{3}$ до суми узагальнених степенів, запишемо коефіцієнти $x^{3}$ у схему Горнера та обчислимо значення даного многочлена в точці 0, частки від ділення в точці 1, отриманої частки в точці 2 і так далі:

\begin{tabular}{|l|l|l|l|l|}
\hline & $\mathbf{1}$ & $\mathbf{0}$ & $\mathbf{0}$ & $\mathbf{0}$ \\
\hline 0 & 1 & 0 & 0 & $\mathbf{0}$ \\
\hline 1 & 1 & 1 & $\mathbf{1}$ & \\
\hline 2 & 1 & $\mathbf{3}$ & \multicolumn{2}{|c}{} \\
\hline 3 & $\mathbf{1}$ & \multicolumn{3}{|c|}{}
\end{tabular}

Запишемо тепер отримані коефіцієнти при узагальнених степенях $x^{(k)}$ для $k=0,1,2,3$ :

$$
x^{3}=0 x^{(0)}+x^{(1)}+3 x^{(2)}+x^{(3)}=x^{(1)}+3 x^{(2)}+x^{(3)} .
$$

Другий спосіб передбачає використання формули $x^{n}=\sum_{k=0}^{n} S(n, k) x^{(k)}$, де $S(n, k)-$ числа Стірлінга другого роду, які широко використовуються в комбінаториці і визначаються рекурентно (Андерсон, 2004):

$S(n+1, k)=S(n, k-1)+k S(n, k) i S(n, 0) ;=0$ при $n>0, S(n, n):=1$.

При $n=3$ одержимо: $S(3,1)=S(2,0)+S(2,1)=1, S(3,2)=S(2,1)+2 S(2,2)=1+2=3, S(3,3)=1$. Тому $x^{3}=\sum_{k=0}^{3} S(3, k) x^{(k)}=S(3,0) x^{(0)}+S(3,1) x^{(1)}+S(3,2) x^{(2)}+S(3,3) x^{(3)}=0 x^{(0)}+x^{(1)}+3 x^{(2)}+x^{(3)}=$

Приклад 7. Обчислити суму $\sum_{k=1}^{n} \frac{k-1}{k !}$. $=x^{(1)}+3 x^{(2)}+x^{(3)}$. 
У цьому випадку $f(x)=\frac{x-1}{x !}$. За пунктом 4) прикладу $3 \Delta^{-1}\left(\frac{x-1}{x !}\right)=-\frac{1}{(x-1) !}$, тому

$$
\sum_{k=1}^{n} \frac{k-1}{k !}=-\left.\frac{1}{(k-1) !}\right|_{1} ^{n+1}=\left(-\frac{1}{n !}+\frac{1}{0 !}\right)=1-\frac{1}{n !}
$$

Розглянемо тепер один із прикладів застосування формули Абеля.

Приклад 8. Обчислити суму

$$
\sum_{k=1}^{n}(k-1) k \cdot 3^{k}=0 \cdot 3^{1}+1 \cdot 2 \cdot 3^{2}+2 \cdot 3 \cdot 3^{3}+. .+n(n-1) \cdot 3^{n}
$$

Нехай $f(x)=x(x-1)=x^{(2)}, \Delta g(x)=3^{x}$, тоді $g(x)=\Delta^{-1} 3^{x}=\frac{3^{x}}{2}$ (див. приклад 3$), \Delta f(x)=2 x, E(g)=\frac{3^{x+1}}{2}$. Застосуємо перетворення Абеля:

$$
\begin{aligned}
\sum_{k=1}^{n}(k-1) k \cdot 3^{k}= & \left.\left(\frac{1}{2} 3^{k} k(k-1)\right)\right|_{1} ^{n+1}-\sum_{k=1}^{n} \frac{2 k}{2} \cdot 3^{k+1}=\left(\frac{3^{n+1}}{2} n(n+1)-0\right)-\sum_{k=1}^{n} k \cdot 3^{k+1}= \\
= & \frac{3^{n+1}}{2} n(n+1)-3 \sum_{k=1}^{n} k \cdot 3^{k} .
\end{aligned}
$$

Обчислимо тепер суму $\sum_{k=1}^{n} k \cdot 3^{k}$. Покладемо $f(x)=x$ і $\Delta g(x)=3^{x}$. Тоді $\Delta f(x)=1, g(x)=\Delta^{-1} 3^{x}=\frac{3^{x}}{2}$,

$E(g)=\frac{3^{x+1}}{2}$. Застосуємо перетворення Абеля ще раз:

$$
\sum_{k=1}^{n} k \cdot 3^{k}=\left.\left(\frac{3^{k}}{2} k\right)\right|_{1} ^{n+1}-\frac{3}{2} \sum_{k=1}^{n} 3^{k}=\frac{3^{n+1}}{2}(n+1)-\frac{3}{2}-\left.\frac{3}{2} \cdot\left(\frac{3^{k}}{2}\right)\right|_{1} ^{n+1}=\frac{3^{n+1}}{2}(n+1)-\frac{3}{2}-\frac{3^{n+2}}{4}+\frac{9}{4}=\frac{3^{n+1}(2 n-1)+3}{4}
$$

$$
\sum_{k=1}^{n}(k-1) k \cdot 3^{k}=\frac{3^{n+1}}{2} n(n+1)-3 \cdot \frac{3^{n+1}(2 n-1)+3}{4}=\frac{3^{n+1}\left(2 n^{2}-4 n+3\right)-9}{4}
$$

Розв'язання будь-якого математичного завдання, що відноситься до опанування математичних понять потребує цілеспрямованості, наполегливості та певних інтелектуальних зусиль. Як показують розглянуті вище приклади, важливим $€$ саме опанування студентами наскрізної ідеї застосування універсальних методів знаходження скінченних сум, в основі якого лежать поняття та інструменти різницевого числення, а не їх конкретна реалізація та проведення громіздких обчислень.

\section{ОБГОВОРЕННЯ}

Вивчення математичних понять у своїх взаємозв'язках відіграє важливу роль у підготовці майбутнього вчителя математики щодо формування у нього наукового світогляду, певного рівня професійної компетентності, особливо за таким компонентам як розуміння сутності практичної спрямованості навчання математики, вміння встановлювати в навчанні внутрішньопредметні та міжпредметні зв'язки. Освоєння фундаментальної теорії дозволить розвинути абстрактне мислення на основі розгляду найважливіших математичних понять у загальному вигляді та у конкретних моделях, розвинути математичне мислення на основі ілюстрації математичних понять, їх зв'язків, прийомів їх побудови, а також прийомів розумової діяльності під час розв'язування завдань, отримати чітке уявлення про використання математичної символіки, отримати достатній досвід математичної діяльності, забезпечує грамотне володіння шкільним математичним курсом.

У багатьох випадках технології навчання фахових математичних дисциплін у вищій школі доцільно доповнювати спеціалізованим програмним забезпеченням з математики - інтегрованими математичними пакетами, які дозволяють розв'язати або перевірити правильність знайдених розв'язків різних математичних задач. Сьогодні ринок програмних продуктів представлений такими інтегрованими математичними пакетами, як Matlab, MathCad, Maple, Mathematica та iн., які органічно можуть бути включені в освітній процес.

Узагальнюючи вищевикладене, можна сказати, що застосування цифрової підтримки навчання фундаментальних дисциплін майбутніх учителів математики дозволить розширити сферу самостійної діяльності студентів за рахунок можливості організації різноманітних видів навчальної діяльності на основу використання цілого арсеналу засобів цифрових технологій, озброїти студента-математика стратегією засвоєння навчального матеріалучи розв'язування завдань певного класу за рахунок реалізації можливостей систем штучного інтелекту, сформувати інформаційну культуру, підготувати випускника ЗВО, який володіє сучасними засобами цифрових технологій, до майбутньої професійної діяльності у Новій українській школі.

\section{ВИСНОВКИ ТА ПЕРСПЕКТИВИ ПОДАЛЬШОГО ДОСЛІДЖЕННЯ}

У статті розглянуто особливості реалізації фундування знань у процесі вивчення математичних понять під час освоєння математичної діяльності в різних математичних курсах засобами цифрових технологій у фаховій підготовці майбутніх учителів математики на прикладі одного із досить універсальних методів знаходження скінченних сум, в основі якого лежать поняття та інструменти різницевого числення. Реалізація такого підходу дозволить сформувати у майбутніх учителів математики знання та уявлення про міжпредметні зв'язки у шкільному курсі математики та інформатики, про способи структурування та візуалізації інформації, про можливості використання цифрових технологій в процесі вивчення шкільного курсу математики, розвивати уміння самостійно збирати, аналізувати, передавати математичну інформацію, використовувати програмні засоби та апаратні пристрої для здійснення збору, обробки, зберігання та передачі інформації, оцінювати та обирати засоби цифрових технологій для організації навчального процесу з математики, усвідомлення сутності та значення інформації в розвитку сучасного інформаційного товариства, усвідомлення можливостей інформаційного середовища для забезпечення якості навчально-виховного процесу в умовах Нової української школи. 


\section{СПИСОК ВИКОРИСТАНИХ ДЖЕРЕЛ}

1. Андерсон, Дж. А. (2004). Дискретная математика и комбинаторика. Москва : Изд. дом «Вильямс».

2. Бекишев, Г.А., \& Кратко, М.І. (1981). Підсумовування послідовностей. Київ : Вища школа, Головне видавництво.

3. Волков, Ю.І., \& Войналович, Н.М. (2000). Елементи дискретної математики. Київ.

4. Лукашова, Т.Д., \& Страх, О.П. (2021). Інтегрований підхід щодо визначення похідної функцій, заданих на неперервних та дискретних множинах. Фізико-математична освіта, 4(30), 76-81. https://doi.org/10.31110/2413-1571-2021-030-4-011

5. Мартиненко, О. В., \& Чкана, Я.О. (2017). Про різні методи знаходження скінченних сум. Фізико-математична освіта, 4(14), 59-67. https://fmo-journal.fizmatsspu.sumy.ua/index/0-35

6. Семеніхіна, О.В., Друшляк, М.Г., \& Хворостіна, Ю. В. (2019). Використання хмарного сервісу GeoGebra у навчанні майбутніх вчителів природничо-математичних дисциплін. Інформаційні технології і засоби навчання, 73(5), 48-66.

7. Страх, О.П., \& Лукашова, Т.Д. (2021). Міждисциплінарні зв'язки при вивченні деяких тем дискретної математики та дифереціальних рівнянь. Фізико-математична освіта, 3(29), 112-118. https://doi.org/10.31110/2413-1571-2021-029-3-017

8. Ушаков, Р. П. (2005). Тотожність Абеля та знаходження скінченних сум. Математика в школах України, 19/21, 2-11.

9. Ушаков, Р. П. (2008). Знаходження сум виду $\sum_{k=1}^{n} k a_{k}$. Математика в школах України, 6(198), $10-16$.

10. Ушаков, Р.П. (2006). Знаходження скінченних сум. Харків: Основа.

11. Ушаков, Р.П. (2004). Первісні послідовності та знаходження скінченних сум. У світі математики,10, 46-57.

12. Ядренко, М.Й. (2004). Дискретна математика. Київ : "ТВіМС".

13. Drushlyak, M.G., Semenikhina, O.V., Proshkin, V. V., Kharchenko, S.Ya., \& Lukashova, T.D. (2020). Methodology of formation of modeling skills based on a constructive approach (on the example of GeoGebra). CTE 2020 Cloud Technologies in Education 2020: Proceedings of the 8th Workshop on Cloud Technologies in Education (CTE 2020) (p. 458-472). Kryvyi Rih, Ukraine, December 18.

14. Drushlyak, M., Semenikhina, O., Bondarenko, Yu., Kondratiuk, S., \& Dehtiarova, N. (2019). Cloud-based service GeoGebra and its use in the educational process: the BYOD-approach. TEM JOURNAL - Technology, Education, Management, Informatics, 8(1), 65-72. DOI: 10.18421/TEM81-08.

15. Drushlyak, M., Semenikhina, O., Zigunova, I., \& Budyanskiy, D. (2018). Geogebra as means of improving the quality of education. Integration, Harmonization, and Knowledge Transfer (ICTERI 2018) : 14th International Conference on ICT in Education, Research, and Industrial Applications (May 14-17, 2018; Kyiv), (p. 331-345). Kyiv.

16. Drushlyak, M., \& Semenikhina, O. (2015). Organization of Experimental Computing in Geogebra 5.0 in Solving Problems of Probability Theory. European Journal of Contemporary Education, 11(1), 82-90.

17. Kelley, W., \& Peterson, A. (2001). Difference Equations: An Introduction with Applications. Second ed. Academic Press.

\section{REFERENCES (TRANSLATED AND TRANSLITERATED)}

1. Anderson, J.A. (2004). Diskretnaja matematika i kombinatorika [Discrete Mathematics with Combinatorics]. Moskow: Ed. house "Williams" (in Russian)

2. Bekishev, G.A., \& Briefly, M.I. (1981). Pidsumovuvannya poslidovnostey [Summarizing sequences]. Kyiv: Higher School, Main Publishing House. (in Ukrainian).

3. Volkov, Y.I., \& Voynalovich, N.M. (2000). Elementy dyskretnoyi matematyky [Elements of discrete mathematics]. Kyiv. (in Ukrainian).

4. Lukashova, T.D., \& Strakh, O.P. (2021). Intehrovanyy pidkhid shchodo vyznachennya pokhidnoyi funktsiy, zadanykh na neperervnykh ta dyskretnykh mnozhynakh [An integrated approach to determining the derivative of functions given on continuous and discrete sets]. Fizykomatematychna osvita - Physical and mathematical education, 4(30), 76-81. (in Ukrainian).

5. Martinenko, O.V., \& Chkana, Ya.O. (2017). Pro rizni metody znakhodzhennya skinchennykh sum [About different methods of finding finite sums]. Fizyko-matematychna osvita - Physical and mathematical education, 4(14), 59-67. (in Ukrainian).

6. Semenikhina, O.V., Drushlyak, M.G., \& Khvorostina, Y.V. (2019). Vykorystannya khmarnoho servisu GeoGebra u navchanni maybutnikh vchyteliv pryrodnycho-matematychnykh dystsyplin [The use of cloud service GeoGebra in the training of future teachers of natural sciences and mathematics]. Informatsiyni tekhnolohiyi i zasoby navchannya-Information technologies and teaching aids, 73(5), 48-66. (in Ukrainian).

7. Strakh, O. \& Lukashova, T. (2021). Mizhdystsyplinarni zviazky pry vyvchenni deiakykh tem dyskretnoi matematyky ta dyferetsialnykh rivnian [Interdisciplinary connections in the study of some topics of discrete mathematics and differential equations]. Fizyko-matematychna osvita - Physical and Mathematical Education, 3(29), 112-118 (in Ukrainian).

8. Ushakov, R.P. (2005). Totozhnist' Abelya ta znakhodzhennya skinchennykh sum [The identity of Abel and finding finite sums]. Matematyka $v$ shkolakh Ukrayiny - Mathematics in schools of Ukraine, 19/21, 2-11. (in Ukrainian).

9. Ushakov, R.P. (2008). Znakhodzhennya sum vydu $\sum_{k=1}^{n} k a_{k}$ [Finding sums of the form $\sum_{k=1}^{n} k a_{k}$ ]. Matematyka v shkolakh Ukrayiny Mathematics in schools of Ukraine, 6 (198), 10-16. (in Ukrainian).

10. Ushakov, R.P. (2006). Znakhodzhennya skinchennykh sum [Finding finite amounts]. Kharkiv: Osnova. (in Ukrainian).

11. Ushakov, R.P. (2004). Pervisni poslidovnosti ta znakhodzhennya skinchennykh sum [Initial sequences and finding finite sums]. $U$ sviti matematyky - In the world of mathematics, 10, 46-57. (in Ukrainian).

12. Yadrenko, M.Y. (2004). Discrete Mathematics: A Textbook [Dyskretna matematyka: Navchalnyi posibnyk]. Kyiv: "TViMS" (in Ukrainian).

13. Drushlyak, M.G., Semenikhina, O.V., Proshkin, V. V., Kharchenko, S.Ya., \& Lukashova, T.D. (2020). Methodology of formation of modeling skills based on a constructive approach (on the example of GeoGebra). CTE 2020 Cloud Technologies in Education 2020: Proceedings of the 8th Workshop on Cloud Technologies in Education (CTE 2020). Kryvyi Rih, Ukraine.

14. Drushlyak, M., Semenikhina, O., Bondarenko, Yu., Kondratiuk, S., \& Dehtiarova, N. (2019). Cloud-based service GeoGebra and its use in the educational process: the BYOD-approach. TEM JOURNAL - Technology, Education, Management, Informatics, 8(1), 65-72. DOI: 10.18421/TEM81-08.

15. Drushlyak, M., Semenikhina, O., Zigunova, I., \& Budyanskiy, D. (2018). Geogebra as means of improving the quality of education. Research, and Industrial Applications: Integration, Harmonization, and Knowledge Transfer (ICTERI 2018) : 14th International Conference on ICT in Education (May 14-17, Kyiv). Kyiv.

16. Drushlyak, M., \& Semenikhina, O. (2015). Organization of Experimental Computing in Geogebra 5.0 in Solving Problems of Probability Theory. European Journal of Contemporary Education, 11(1), 82-90.

17. Kelley, W. \& Peterson, A. (2001). Difference Equations: An Introduction with Applications. Second edition. Academic Press.

\section{$(\mathrm{cc}) \mathrm{BY}-\mathrm{NC}-\mathrm{SA}$}

This work is licensed under Creative Commons Attribution-NonCommercial-ShareAlike 4.0 International License. 